\title{
THE MARKET OF FUNCTIONAL FOODS
}

\author{
Tímea Balogh ${ }^{1 *}$, Irén Köszegi ${ }^{2}$, Edit Hoyk ${ }^{3}$ \\ ${ }^{1}$ student, Faculty of Horticulture and Rural Development, John von Neumann University, Hungary \\ ${ }^{2}$ Department of Agroecomony and Rural Development, Faculty of Horticulture and Rural Development, John \\ von Neumann University, Hungary \\ ${ }^{3}$ Department of Agroecomony and Rural Development, Faculty of Horticulture and Rural Development, John \\ von Neumann University, Hungary
}

Great Plain Research Department, Institute for Regional Studies, Centre for Economic and Regional Studies, Hungary

https://doi.org/10.47833/2020.2.AGR.031

\section{Keywords: \\ functional foods \\ conventional foods \\ market}

$\begin{array}{ll}\text { Article history: } \\ \text { Received } & 5 \text { May } 2020 \\ \text { Revised } & 28 \text { April } 2020 \\ \text { Accepted } & \text { 1 June } 2020\end{array}$

\begin{abstract}
In our work, we compare conventional foods with functional foods in terms of consumer perception. Nowadays, in addition to conventional foods, the production of functional foods is becoming more and more widespread globally, including in Hungary. Recently, there is a growing interest in so-called functional foods, hoping that these products are guaranteed to contain a slightly healthier nutrient composition than products made from conventionally (traditionally) grown ingredients. All this opens a new chapter in today's agricultural production and food production. Consumers are looking for functional foods that inspected and certified, can provide greater safety for consumers, as opposed to conventional foods. But like most healthy foods, functional foods represent a higher price than products that are considered the same in the category but are not "medicinal”.
\end{abstract}

\section{Introduction}

In our work, we compare conventional foods with functional foods in terms of consumer perception. Nowadays, in addition to conventional foods, the production of functional foods is becoming more and more widespread globally, including in Hungary. Recently, there is a growing interest in so-called functional foods, hoping that these products are guaranteed to contain a slightly healthier nutrient composition than products made from conventionally (traditionally) grown ingredients. All this opens a new chapter in today's agricultural production and food production. Consumers are looking for functional foods that inspected and certified, can provide greater safety for consumers, as opposed to conventional foods. But like most healthy foods, functional foods represent a higher price than products that are considered the same in the category but are not „medicinal”.

\section{Titles and subtitles}

\subsection{Functional food market - market acceptance}

Demand for functional foods only began to grow significantly in the 1990s. The annual growth rate is estimated at $10-12 \%$. Most likely this growth rate will decline over the next decade, but will still be on the order of magnitude higher than the $2 \%$ growth rate of total food demand. In emerging

\footnotetext{
* Corresponding author. E-mail address: baloghtimea1122@gmail.com
} 
markets, such as Hungary, Russia and Poland, growth is forecast to be close to average. This market is concentrated in three main areas, the United States, Europe and Japan. More than $90 \%$ of sales of functional products take place in these regions. In the field of functional foods, the market share in Europe is only around 1\%, while in the US it is 3\%, but further forecasts are not expected to exceed $5 \%$ in the future. The following products account for the largest share of these food sales: confectionery, bakery and cereal products, dairy products and non-alcoholic beverages. The most popular of these are dairy products. In the regions just listed, the most important products for each disease are different. In Europe and Japan, foods that have a beneficial effect on the digestive system are the most significant, while in the United States, cardiovascular and cancer-related foods are the most important [1]. Within Europe, the most important countries in the functional food market are France, the Netherlands and Germany [2]. Functional foods are renewable products, where changing consumer habits and market trends are renewable sources. On the one hand, the Hungarian economy and Hungarian consumers are quite open to the international market, and on the other hand, they are significantly receptive to the international trends. Due to changing consumer habits, fast-growing economies, including Hungary, have a high growth potential. It is observed in these economies that health awareness is increasing. Experts are optimistic about the growth situation of functional foods [3].

It can be shown that functional foods are becoming more and more popular among consumers globally, in which the formation of health-conscious consumer groups and the system of companies supporting a healthy lifestyle play a prominent role. The growth of functional foods can also be felt in Hungary, but domestic demand has a number of limiting factors, such as the income situation of consumers, the price of products and the lack of information and mistrust of consumers about functional foods. In the last decade, the structure of food consumption in Hungary has moved to a positive range, so the emphasis on healthy nutrition and the introduction of healthy products introduced by companies will play an important role [4].The importance of information and the acceptance of innovation is growing, as a result of which new target groups have appeared [5]. One such target group is LOHAS - Lifestyle of Health and Sustainability - who are environmentally and health conscious consumers. A consumer group whose members are guided by moral considerations in their decisions, in addition, they consider the environment and take into account the impact on health in their purchasing decisions. Simultaneously with the emergence of new consumer needs and preferences, and in order to satisfy these needs, more and more food industry companies involve tasks and elements emphasizing a healthy lifestyle in their organizations [6].

A suitable example of this in Hungary is the Hungarian food chain called CBA, the main goal of which is to develop the general awareness of society. The CBA keeps in mind the nutritional principles of consumers and then compiles its own product list based on this. Based on his observations, the result of their method is already noticeable, as consumer behaviour has moved in a positive direction, although it is a slow process [7]. The Nestlé Nutrition Institute also has an important goal to make people live healthier lives. Their vision is to become the most well-known company in healthy foods and nutrition, which they want to achieve by producing foods that affect the quality of life and health of their customers [8].

\section{Material and methods}

\subsection{Material}

Functional food is a relatively new interpretation, the wording of which, as well as the food industry qualification and procedural regulations, are related to Japan. The concept of functional food first appeared in Japan in the 1930s, and till nowadays there is no uniformly accepted definition, as it is difficult for experts to define this food category, both abroad and domestically. In addition, the available sources are very different, resulting in different wordings. The role of this food category can be traced back to the 1980s, when the Ministry of Health and Welfare of Japan initiated the regulation of foods with such health benefits in order to improve the public health situation. However, it first appeared in trade only in the 1990s, and since then its sales volume has been increasing. In Japan, there is a special name for functional foods, which is as follows; "Foods with specific health benefits" [9]. 


\subsection{Methods}

We used a computer-based survey method to conduct our research. A total of 168 questionnaires were completed. The survey began on 12 September 2019 and ended on 10 October 24. The survey was conducted among domestic consumers, which cannot be considered representative, but it can give a collective picture of how consumers perceive functional foods and healthy - health-conscious - nutrition. Respectively, whether consumers know the difference between functional and conventional foods and what difference they notice between them.

\section{Results}

For the „What are the reasons for buying functional food?" question multiple answers could be marked. "Self inspiration" category has been marked in many cases. It is likely to be related to a cause or problem arising from a medical condition, as a result of which the respondent sought to acquire relevant knowledge about the situation, either with or without medical advice. Contrary to the previous statement, the respondent may just want to lead a healthier lifestyle or consume it for preventative purposes. One of the ways to obtain the information could be the already mentioned medical advice, or information obtained from friends/acquaintances, in addition, the respondent could get information from the media (TV, radio, newspaper). The marked "Internet" response shows that one of the fastest ways to obtain information is the World Wide Web, and therefore plays a key role in awareness (Fig. 1.).

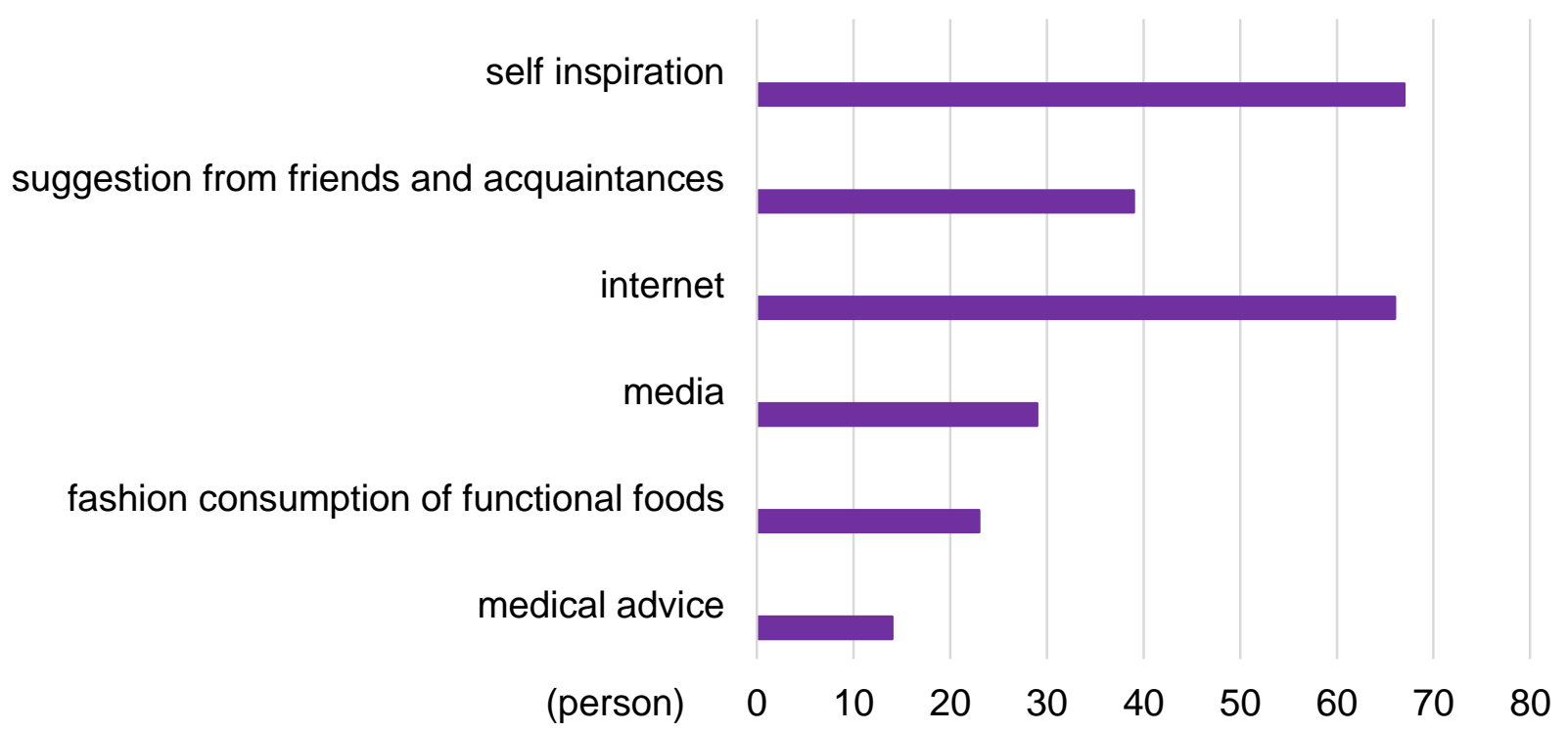

Figure 1.: Survey on the purchase of functional food in proportion to the number of responses $(\mathrm{N}=168)$

Source: Own survey, 2019.

Nearly $80 \%$ of respondents consume functional food on a daily or weekly basis (Fig. 2.). The response rate obtained is favourable for daily, weekly consumption, which supports the fact that in today's accelerated lifestyle and in line with the answers to previous questions related to a healthy lifestyle, they are trying to lead a truly healthy life. Within this, women are more active in seeking and consuming functional foods, while men are less likely to buy such foods. This may be because usually women do the shopping, as they are mostly the ones who run the household. We examined the relationships between consumption and place of residence in the proportion of responses, which revealed that multiple and higher levels of functional food consumption are shifting toward cities. It can be said that urban population buy almost the same proportion of traditional and functional foods daily and several times a week (Fig. 2.). 


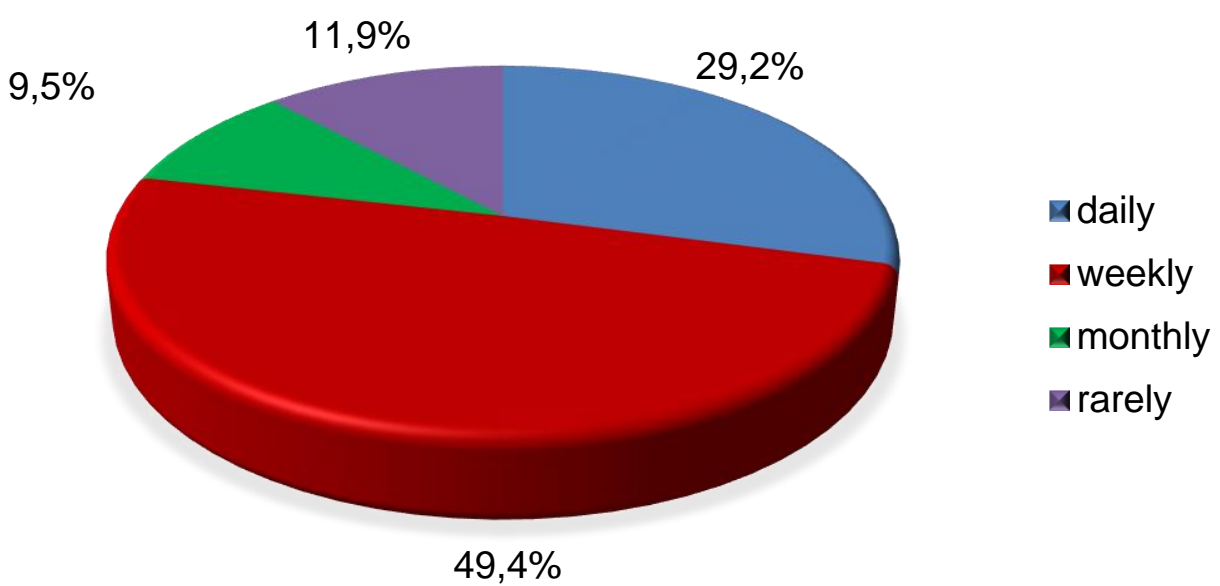

Figure 2.: Distribution of the frequency of functional food consumption among the respondents $(\mathrm{N}=168)$

Source: Own survey, 2019.

Regarding the experience of consumers about functional foods (Fig. 3.), the majority of respondents $(71 \%)$ are satisfied with these foods. Satisfaction with functional foods was presumably prevalent among those living in the city - presumably with a higher income level - and within this it was more common among women. Buyers who find these foods expensive will certainly have lower incomes or are simply unwilling to pay more than usual. The reasons for marking the "I expected more" option may be that they did not experience a significant beneficial effects in their body in the long run, or they did not meet their ideas and needs. In this respect, the response rate of men was more decisive.

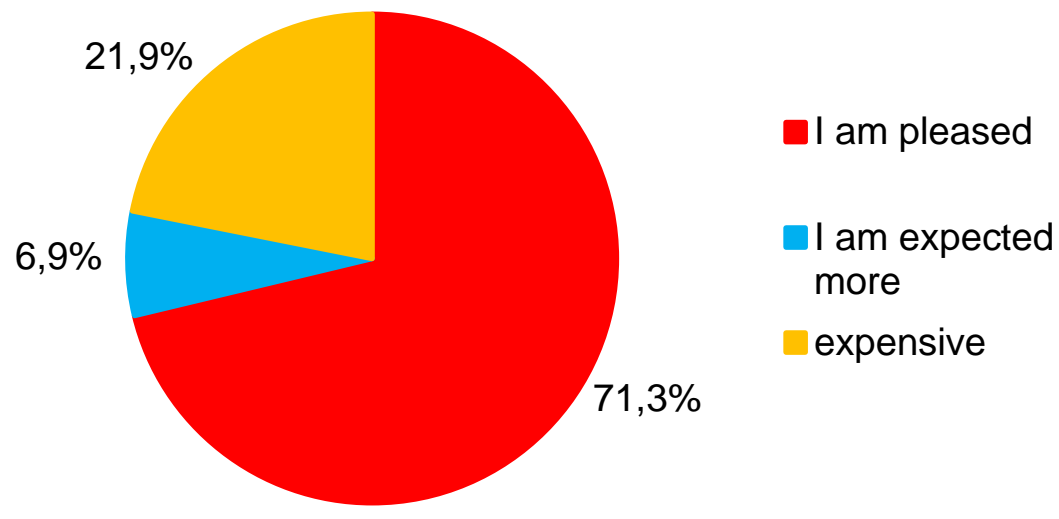

Figure 3.: Respondents' satisfaction with functional foods ( $\mathrm{N}=160)$ Source: Own survey, 2019.

We surveyed where consumers get the functional foods they want to buy (Fig. 4.). The proportion of responses shows that purchase of functional food in hypermarkets and supermarkets is the most common. For convenience, the hypermarket/supermarket is still preferred during the shopping process. 


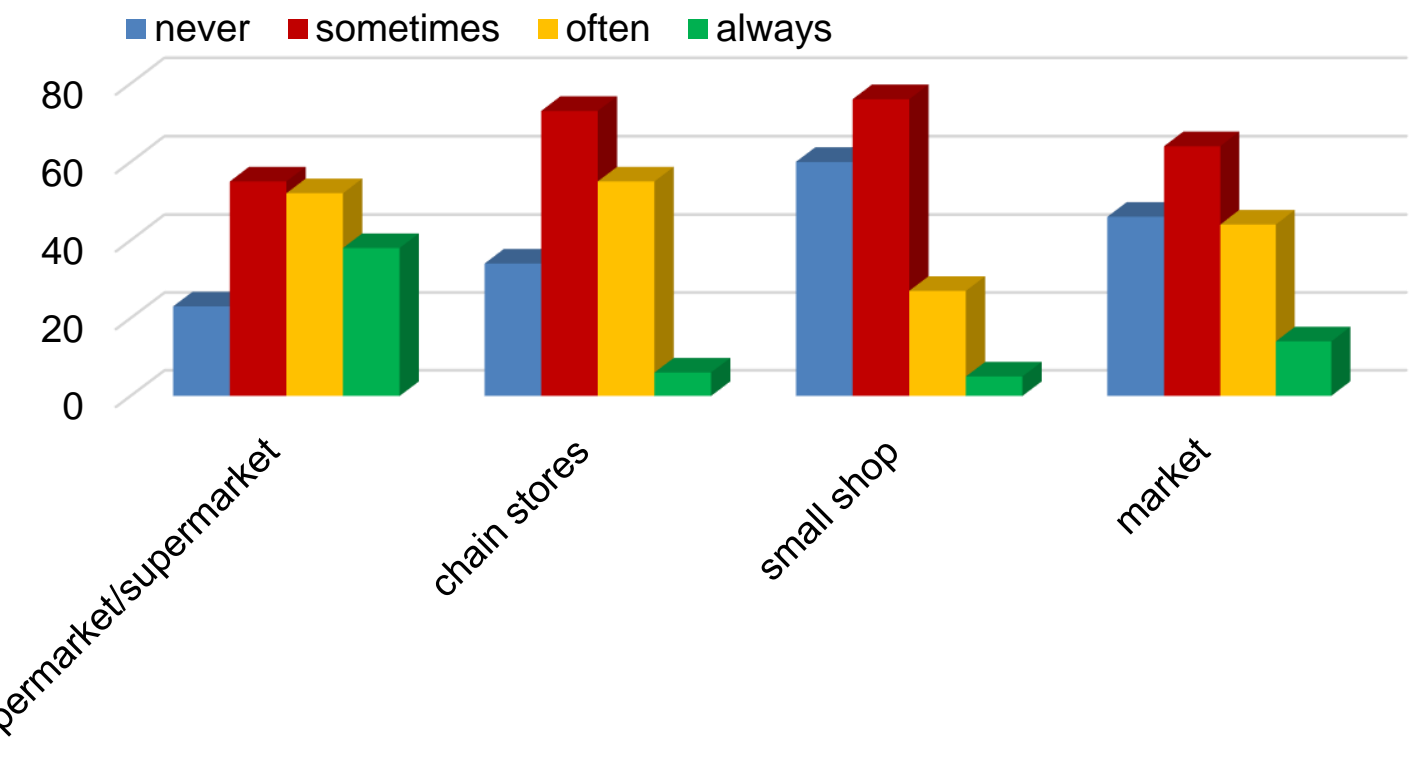

Figure 4.: Frequency of procurement of functional food by location $(\mathrm{N}=168)$ Source: Own survey, 2019.

\section{Conclusions, suggestions}

Looking at Hungary, we can say from the research results of the topic that domestic consumers are looking for healthier foods more purposefully than before. At the same time, the susceptibility to conscious nutrition is mainly influenced by price sensitivity (scarce financial situation). Despite this health consciousness and expectations about healthy food categories are increasing. Based on these, it can be concluded, that health awareness among the Hungarian population is even lower, but the majority are open to relevant information related to health, healthy food and nutrition. This, in turn, supports the fact that there is a growing demand for healthier, in this case functional foods. In our opinion, with a proper education, the number of conscious customers could increase significantly in the future.

\section{Acknowledgment}

This research is supported by EFOP-3.6.1-16-2016-00006 "The development and enhancement of the research potential at John von Neumann University" project. The Project is supported by the Hungarian Government and co-financed by the European Social Fund.

\section{References}

[1] LEHOTA J. - KOMÁROMI N. (2007): A funkcionális tejtermékek fogyasztói magatartásának összetevői, Élelmiszer, Táplálkozás és Marketing, Vol. 4, No. 1. p. 33.

[2] SÍRÓ I. - KÁPOLNA E. - KÁPOLNA B. - LUGASI A. (2008): Functional food. Product development, marketing and consumer acceptance, A review, Appetite, Vol.51. pp. 456-467.

[3] PISKÓTI I. - NAGY SZ. - KOVÁCS A. T. (2006): Fogyasztói magatartás a funkcionális élelmiszerek piacán, Gazdász Elasztik Kft, Miskolc. pp. 117-127.

[4] SZAKÁLY Z. (2004): Táplálkozásmarketing, egy új stratégia a magyar élelmiszer-gazdaságban, Élelmiszer, Táplálkozás és Marketing, Vol. 1. No. 1-2. pp. 1-24.

[5] SZAKÁLY Z. (2008): Trendek és tendenciák a funkcionális élelmiszerek piacán: Mit vár el a hazai fogyasztó, Élelmiszer, Táplálkozás és Marketing, Vol. 5, No. 2-3. pp. 7-9.

[6] TÖRÖCSIK M. (2007): A tudatos fogyasztást és az egészséget preferáló új fogyasztói trendcsoport a LOHAS csoport megjelenése Magyarországon, Élelmiszer, Táplálkozás és Marketing, Vol. 4, No. 1. pp. 1-5.

[7] SZILVÁSI M. - ZARKA J. - HORVÁTH J. (2007): A CBA élelmiszerlánc stratégiája az egészséges élelmiszerek piacán, Élelmiszer, Táplálkozás és Marketing, Vol. 4, No. 1. pp. 65-66. 
[8] CSONTOS CS. (2009): A Nestlé Nutrition küldetése: Segíteni az embereknek, hogy egészségesebben és tovább éljenek, Élelmiszer, Táplálkozás és Marketing, Vol. 4, No. 1-2. pp. 97-98.

[9] BíRÓ GY. (2003): Funkcionális élelmiszerek, természetes antioxidánsok szerepe az egészségmegörzésben, Élelmezési ipar, Vol. 57, No. 4. pp. 117-123. 